\title{
ASAS KEBEBASAN BERKONTRAK DALAM PEMBERIAN KESEMPATAN PENYELESAIAN PEKERJAAN PENGADAAN BARANG/JASA PEMERINTAH (PBJP)
}

\author{
Ajik Sujoko \\ Fakultas Hukum Universitas Diponegoro \\ J1. Prof. Soedarto, S.H. Tembalang, Semarang \\ ajik.sujoko80@gmail.com
}

\begin{abstract}
PBJP contracts include standard contracts provided as freedom contracts. Providing opportunities for work completion in contract implementation. PBJP saw from the application of the theory of fusion (opplosing theory) and the concept of Private-Administration Contracts. Following the theory of fusion which is a private contract, the relationship between "kontraktan", as a work agreement, not as the authority of the government as "kontraktan", but on the contractual relationship of an agreement between "rights and obligations". Based on the concept of Private-Contract Administration, providing opportunities is no longer seen in the "rights and obligations" in the contract, but the authority of the government as "kontraktan" in making work done by the provider can be completed.
\end{abstract}

Keywords: The Principle of Freedom of Contract; Giving Oportunity

\begin{abstract}
Abstrak
Kontrak PBJP termasuk kontrak baku yang terdapat pembatasan asas kebebasan kontrak. Pemberian kesempatan penyelesaian pekerjaan dalam pelaksanaan kontrak PBJP dilihat dari penerapan teori melebur (opplosing theory) maupun konsep Privat-Administrative Contract. Sesuai teori melebur yang merupakan kontrak privat, hubungan antara "kontraktan" sebagai upaya menyelesaikan pekerjaan, bukan sebagai kewenangan pemerintah sebagai "kontraktan", namun pada hubungan kontraktual didasarkan pada antara "hak dan kewajiban". Berdasar konsep Privat-Administrative Contract, pemberian kesempatan bukan lagi dipandang pada "hak dan kewajiban" dalam berkontrak, namun wewenang pemerintah sebagai kontraktan dalam mengupayakan pekerjaan yang dilakukan oleh penyedia dapat selesai.
\end{abstract}

Kata Kunci: Asas Kebebasan Berkontrak; Pemberian Kesempatan

\section{A. Pendahuluan}

Asas-asas yang bersifat dasariah berkenaan dengan keberadaan kontrak, seperti asas kebebasan berkontrak, asas pacta sunt servanda, asas itikad baik, asas kewajaran, dan sebagainya masih tetap menjadi pondasi utama kontrak dan hukum kontrak (Hardjowahono 2013). Dari beberapa penelitian mengenai asas kebebasan berkontrak menunjukkan bahwa terjadi pembatasan dalam asas kebebasan berkontrak, khusunya dalam perjanjian standar baku. Perjanjian baku adalah suatu perjanjian yang di dalamnya telah terdapat syarat-syarat tertentu yang dibuat oleh salah satu pihak, yang umumnya disebut perjanjian adhesie atau perjanjian baku (Jamilah 2012). Perjanjian baku memiliki ciri khas antar lain isinya ditetapkan secara sepihak yang lebih kuat dan adanya klausula/syarat eksonerasi (syarat yang membatasi atau memebebaskan tanggung jawab salah satu pihak (Hendrawati 2011). 
PBJP merupakan suatu aktivitas ekonomi. One of four major economic activities; purchasing goods, services and capital assets(Thai 2001). Aktivitas ekonomi dalam PBJP yang dibuat dalam suatu kontrak juga terjadi adanya pembatasan terhadap asas kebebasan berkontrak. Dalam kontrak yang berbentuk "Surat Perjanjian" condong bercirikan perjanjian standar baku. Hal ini dilihat dari pemerintah yang diwakili oleh Pejabat Pembuat Komitmen (PPK) biasa menetapkan draft Surat Perjanjian sebelum proses tender/seleksi dimulai yang didalamnya memuat skema atau klausulklausul. Draft Surat Perjanjian sebelum proses tender/seleksi ini yang nantinya disempurnakan dan ditandatangani antara PA/KPA/PPK dengan Penyedia.

Dalam pelaksanaan kontrak, skema atau klausul-klausul akan diuji apakah pekerjaan yang diperjanjikan dalam kontrak/surat perjanjian akan diselesaikan oleh penyedia sesuai waktu yang diberikan atau tidak. Beberapa permasalahan dalam pelaksanaan kontrak PBJP adalah penyedia tidak bisa menyelesaikan pekerjaan sesuai waktu yang diberikan. Salah satu opsi untuk menyelesaikan permasalahan tersebut adalah dengan pemberian kesempatan. Pemberian kesempatan dikorelasikan dengan adanya gagalnya penyedia menyelesaikan pekerjaan sampai masa pelaksanaan kontrak berakhir (Sujoko 2019). Ketika terjadi pemberian kesempatan, maka administrasi pemberian kesempatan dimuat dalam addendum kontrak.

Dalam praktek pelaksanaan kontrak bahkan di pasca pelaksanaan kontrak (kontrak telah berakhir) ditemukan beberapa pekerjaan di PBJP pemberian kesempatan tidak disertai adanya addendum berupa pemberian kesempatan. Sebagai contoh kasus yang telah ada seperti Putusan PN Surabaya Nomor 99/PID-SUS/ TPK/2014/PN Sby. adalah memberi kesempatan kepada penyedia untuk melanjutkan pekerjaan tanpa addendum. Yurisprudensi Mahkamah Agung Tahun
2018 Bidang Pidana Khusus, A. 1/Yur/Kor/2018 juga dijelaskan contoh kasus telah mencairkan pembayaran secara penuh padahal pekerjaan belum selesai $100 \%$, namun dikarenakan tidak adanya addendum kontrak dan tidak adanya penjatuhan denda penalti keterlambatan, walaupun pekerjaan tersebut pada akhirnya telah selesai dan telah diserahterimakan, Terdakwa tetap disebut telah merugikan keuangan negara. Menurut penulis, putusan semacam ini adalah putusan yang janggal, di mana kesalahan dalam administrasi maupun kontrak dimasukkan dalam ranah pidana. Dari contoh kasus tersebut cukup menarik untuk didiskusikan bagaimana penerapan asas kebebasan berkontrak dalam menjelaskan ketentuan kontrak yang dilanggar terkait pemberian kesempatan. Apakah hal tersebut dianggap kesalahan administrasi yang mengacu pada hukum administrasi negara atau pelanggaran kontrak yang merupakan undang-undang bagi para pihak yang berlandaskan pada asas kebebasan berkontrak?

\section{B. Pembahasan}

\section{Praktek Pembatasan Asas Kebebasan Berkontrak di beberapa Bidang}

Dalam beberapa bidang, pembatasan terhadap asas kebebasan berkontrak banyak dilakukan, khususnya dalam perjanjian baku. Tabel 1 berikut contoh perjanjian baku dalam beberapa bidang: 
Tabel 1.

Contoh Perjanjian Baku dalam Beberapa Bidang

\begin{tabular}{|c|c|c|c|c|c|}
\hline $\begin{array}{c}\text { Bidang } \\
\text { Pengaturan }\end{array}$ & Peraturan & $\begin{array}{l}\text { Piha } \\
\text { Pembuat } \\
\text { perjanjian }\end{array}$ & -pihak & $\begin{array}{l}\text { Implemen- } \\
\text { tasi }\end{array}$ & Contoh \\
\hline $\begin{array}{l}\text { Perlindungan } \\
\text { Konsumen }\end{array}$ & $\begin{array}{l}\text { UU No. } 8 \text { Tahun } 1999 \\
\text { tentang } \\
\text { Perlindungan Konsumen }\end{array}$ & Pelaku usaha & Konsumen & Swasta & $\begin{array}{l}\text { Kontrak Berlangganan } \\
\text { Sambungan } \\
\text { Telekomunikasi Telepon } \\
\text { Selular Pasca Bayar }\end{array}$ \\
\hline \multirow[t]{2}{*}{$\begin{array}{l}\text { Ketenagakerj } \\
\text { aan }\end{array}$} & $\begin{array}{l}\text { UU No. } 13 \text { Tahun } 2003 \\
\text { tentang } \\
\text { Ketenagakerjaan }\end{array}$ & Pengusaha & Pekerja/buruh & Swasta & $\begin{array}{l}\text { Perjanjian Kerja antara } \\
\text { Karyawan dengan } \\
\text { Perusahaan }\end{array}$ \\
\hline & & Pengusaha & Pekerja/buruh & Pemerintah & $\begin{array}{l}\text { Perjanjian Kerja antara } \\
\text { Tenaga kerja dengan } \\
\text { Perusahaan dalam } \\
\text { Outsourcing di } \\
\text { pemerintah }\end{array}$ \\
\hline Perbankan & $\begin{array}{l}\text { UU No. } 10 \text { Tahun } 1998 \\
\text { tentang } \\
\text { Perubahan Atas Undang- } \\
\text { Undang Nomor } 7 \text { Tahun } \\
1992 \\
\text { Tentang Perbankan }\end{array}$ & Bank & Nasabah & Swasta & Perjanjian Kredit \\
\hline $\begin{array}{l}\text { Pengadaan } \\
\text { Barang/Jasa }\end{array}$ & $\begin{array}{l}\text { Perpres No. } 16 \text { Tahun } \\
2018 \text { tentang Pengadaan }\end{array}$ & Pemerintah & Pelaku usaha & Pemerintah & Perjanjian PBJP \\
\hline $\begin{array}{l}\text { Pemerintah } \\
(\mathrm{PBJP})\end{array}$ & Barang/Jasa Pemerintah & $\begin{array}{l}\text { Pelaku usaha } \\
\text { utama } \\
\text { (dalam } \\
\text { beberapa } \\
\text { praktek) }\end{array}$ & Subkontraktor & Swasta & $\begin{array}{l}\text { Perjanjian Subkontrak } \\
\text { dalam PBJP }\end{array}$ \\
\hline
\end{tabular}

Dari tabel 1 di atas dapat dilihat, bahwa bidang pengaturan mengenai perlindungan konsumen, ketenagakerjaan dan perbankan, peraturan yang memayungi adalah setingkat Undang-Undang (UU), sedangkan bidang pengaturan PBJP adalah setingkat Peraturan Presiden (Perpres). Pembuat perjanjian dilakukan secara sepihak. Contoh kontrak berlangganan sambungan telekomunikasi telepon selular pasca bayar harus memuat klausul sesuai dengan Undang-Undang Perlindungan Konsumen, khususnya dibatasi dengan ketentuan Pasal 18 Undang-Undang Perlindungan Konsumen (Elis Herlina dan Sri Santi 2016). Pembatasan klausul tersebut setingkat dalam peraturan yang berbentuk Undang-Undang. Perjanjian Kerja antara Tenaga kerja dengan Perusahaan dalam
Outsourcing di pemerintah juga terdapat pembatasan kebebasan terhadap kontrak yang dibuat antara pengusaha dengan tenaga kerja. Dalam perjanjian kerja inilah hak dan kewajiban antara pekerja outsourcing dengan penyedia dijelaskan, termasuk di dalamnya mengenai upah dan kesejahteraan (Sujoko 2018). Pembatasan kebebasan berkontrak antara pengusaha dengan tenaga kerja karena harus mengikuti ketentuan perjanjian kerja/kontrak antara pemerintah dengan pengusaha. Artinya pembatasan kebebasan berkontrak antara pengusaha dengan tenaga dibatasi dengan kontrak antara pemerintah dengan pengusaha. 


\section{Interpretasi atau Pemahaman atas Asas Kebebasan Berkontrak}

Sebagai asas yang bersifat universal yang bersumber dari paham hukum, asas kebebasan berkontrak muncul bersamaan dengan lahirnya paham ekonomi klasik yang mengagungkan laissez faire atau persaingan bebas (Hernako 2010). Sekalipun asas ini tidak secara eksplisit dimaktubkan ke dalam perundang-undangan, kebebasan berkontrak ini muncul dalam pengakuan umum serta pengaturan kontrak (Budiono 2006).

Menurut pandangan umum Tim Perumus Naskah Akademik RUU Hukum Kontrak BPHN Kementerian Hukum Dan HAM RI 2013 atas asas-asas umum hukum perjanjian, bila dipandang dari perspektif nilai-nilai dasar Pancasila (Hardjowahono 2013) sebagai berikut:

"Asas kebebasan berkontrak (freedom of contract) yang menjadi dasar pembentukan perjanjian dan pelaksanaan perjanjian, ditinjau dari cara-pandang Pancasila, harus dipahami sebagai kebebasan yang terbatas. Artinya, kebebasan pihak-pihak untuk bersepakat tentang isi, bentuk, persyaratan, dsb dari perjanjian mereka haruslah dikendalikan oleh prinsip kesederajatan, penghormatan atas perbedaan kedudukan dan kepentingan masing-masing pihak dan pihak ketiga (individu atau masyarakat), serta oleh nilai-nilai moralitas yang terbit karena pertanggungjawaban vertikal manusia pada Sang Pencipta (kejujuran, itikad baik keterbukaan). Perjanjian yang dibuat dan/atau dilaksanakan dengan menyalahiprinsip-prinsip serta nilainilai itu dapat dianggap kehilangan sifat keluhurannya (sanctity)."'

Dengan wujudnya campur tangan negara, maka eksistensi asas kebebasan berkontrak seperti dalam perjanjian kerja antara pengusaha dan pekerja/buruh, khusunya dalam PBJP dalam membentuk perjanjian kerja menjadi sangat terbatas (Santoso and T 2012).

\section{Pandangan mengenai B.W. di Indonesia dan Asas Kebebasan Berkontrak}

Buku III BW menganut sistem terbuka, artinya memberi keleluasan kepada para pihak untuk mengatur sendiri pola hubungan hukumnya (Hernako 2010). Menurut Hukum Perdata yang berlaku di Indonesia, kebebasan berkontrak dapat disimpulkan dari ketentuan dalam Pasal 1338 ayat (1) KUH Perdata yang menyatakan bahwa "semua kontrak (perjanjian) yang dibuat secara sah berlaku sebagai Undang-Undang bagi mereka yang membuatnya.(Budiwati n.d.) Kebebasan Berkontrak yang dapat diberikan dari Pasal 1338 (1) KUH Perdata dibatasi oleh ketentuan yang ada dalam Pasal 1320 (1), yang menentukan bahwa perjanjian atau kontrak tidak sah apabila dibuat tanpa adanya konsensus atau kesepakatan diantara para pihak yang membuatnya (Budiwati n.d.).

C.S.T Kansil menyampaikan pandangannya mengenai B.W. di Indonesia sebagai rechtsboek (Kitab Hukum) bukan wetsboek (Kitab Undang-undang), sehingga Pengadilan (Hakim) dapat mengesampingkan suatu pasal jika dianggap bertentangan dengan jaman kemerdekaan (Hardjowahono 2013). Dalam perkembangannya pada tahun 1962 pada rapat Badan Perancang Lembaga Pembinaan Hukum Nasional Menteri Sahardjo menyatakan bahwa KUHPerdata/BW bukan lagi sebagai "Wetboek" tetapi sebagai "Rechtsboek" yang hanya dipakai sebagai pedoman (Hardjowahono 2013). Pakar hukum Adat Indonesia, Prof. Mahadi menyetujui gagasan tersebut dan menyatakan bahwa KUHPerdata/BW sebagai kodifikasi tidak berlaku lagi dan yang masih berlaku ialah aturan-aturan yang tidak bertentangan dengan semangat dan suasana kemerdekaan, yang diperkuat oleh Surat Edaran Mahkamah Agung (SEMA) No 3 tahun 1963 (Hardjowahono 2013).

Pandangan lain yang dikemukakan oleh Sutan Remy Sjahdeini menarik pula untuk diperhatikan, bahwa: (Hardjowahono 2013) 
“ ...[t]idak setiap tingkat peraturan perundang-undangan dapat membatasi asas kebebasan berkontrak. Asas kebebasan berkontrak keberadaan dan berlakunya ditentukan dan diakui oleh peraturan perundang-undangan yang bertingkat undang -undang, yaitu KUH Perdata. Oleh karena itu, Undang undang atau peraturan pemerintah pengganti undang - undang atau peraturan perundangan yang bertingkat lebih tinggi saja yang mempunyai kekuatan hukum untuk membatasi bekerjanya asas kebebasan berkontrak."

\section{Pemberian Kesempatan Penyelesaian Pekerjaan Dilihat Aspek Administrasi dalam Pengadaan Barang/Jasa Pemerintah}

Beberapa ketentuan mengenai pemberian kesempatan penyelesaian pekerjaan dalam PBJP dapat dilihat seperti tabel 2 berikut:

Tabel 2.

Beberapa Ketentuan mengenai Pemberian Kesempatan Penyelesaian Pekerjaan dalam PBJP

\begin{tabular}{|c|c|c|}
\hline \multicolumn{3}{|c|}{ Ketentuan Mengenai Pemberian Kesempatan Penyelesaian Pekerjaan } \\
\hline $\begin{array}{l}\text { Perpres No } 16 \text { Tahun 2018; } \\
\text { Pasal } 56 \\
\text { (1) Dalam hal Penyedia gagal } \\
\text { menyelesaikan pekerjaan sampai } \\
\text { masa pelaksanaan Kontrak } \\
\text { berakhir, namun PPK menilai } \\
\text { bahwa Penyedia mampu } \\
\text { menyelesaikan pekerjaan, PPK } \\
\text { memberikan kesempatan Penyedia } \\
\text { untuk menyelesaikan pekerjaan. } \\
\text { (2) Pemberian kesempatan kepada } \\
\text { Penyedia untuk menyelesaikan } \\
\text { pekerjaan sebagaimana dimaksud } \\
\text { pada ayat (1), dimuat dalam } \\
\text { adendum kontrak yang di dalamnya } \\
\text { mengatur waktu penyelesaian } \\
\text { pekerjaan, pengenaan sanksi denda } \\
\text { keterlambatan kepada Penyedia, } \\
\text { dan perpanjangan Jaminan } \\
\text { Pelaksanaan. } \\
\text { (3) Pemberian kesempatan kepada } \\
\text { Penyedia untuk menyelesaikan } \\
\text { pekerjaan sebagaimana dimaksud } \\
\text { pada ayat (1), dapat melampaui } \\
\text { Tahun Anggaran. }\end{array}$ & 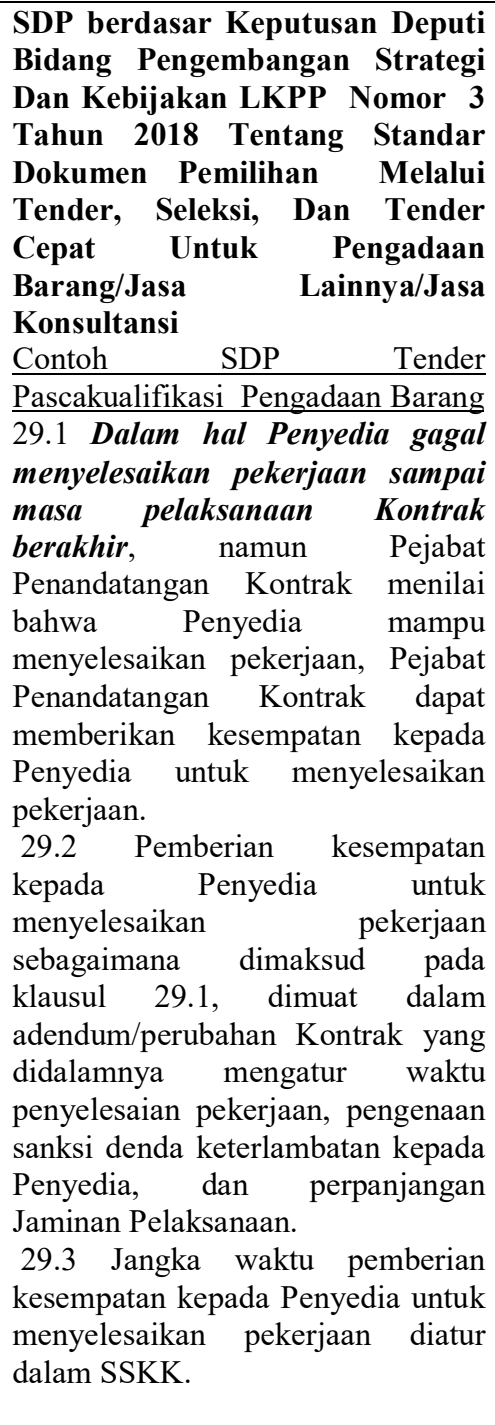 & $\begin{array}{l}\text { Standar Dokumen berdasar } \\
\text { PerMenPUPR Nomor } \\
\text { 07/Prt/M/2019 Tentang Standar } \\
\text { Dan Pedoman Pengadaan Jasa } \\
\text { Konstruksi Melalui Penyedia } \\
\text { Contoh Standar Dokumen Tender } \\
\text { Secara Elektronik, Pengadaan } \\
\text { Pekerjaan Konstruksi, Metode } \\
\text { Tender, Prakualifikasi, Dua File, } \\
\text { Sistem Nilai, Kontrak Gabungan } \\
\text { Lumsum dan Harga Satuan } \\
\text { 45.1 Dalam hal diperkirakan } \\
\text { Penyedia gagal menyelesaikan } \\
\text { pekerjaan sampai } \\
\text { Pelaksanaan berakhir, namun PPK } \\
\text { menilai bahwa Penyedia mampu } \\
\text { menyelesaikan pekerjaan, PPK } \\
\text { dapat memberikan kesempatan } \\
\text { kepada Penyedia } \\
\text { menyelesaikan pekerjaan. } \\
\text { 45.2 Pemberian kesempatan kepada } \\
\text { Penyedia untuk menyelesaikan } \\
\text { pekerjaan dimuat dalam adendum } \\
\text { Kontrak yang didalamnya mengatur: } \\
\text { a. waktu pemberian kesempatan } \\
\text { penyelesaian pekerjaan; } \\
\text { pengenaan banksi denda } \\
\text { keterlambatan kepada Penyedia; c. } \\
\text { perpanjangan masa berlaku Jaminan } \\
\text { Pelaksanaan; dan d. sumber dana } \\
\text { untuk membiayai penyelesaian sisa } \\
\text { pekerjaan yang akan dilanjutkan ke } \\
\text { Tahun Anggaran berikutnya dari } \\
\text { DIPA Tahun Anggaran berikutnya, } \\
\text { apabila pemberian kesempatan } \\
\text { melampaui Tahun Anggaran. } \\
\text { 45.3 Pemberian kesempatan kepada } \\
\text { Penyedia menyelesaikan pekerjaan }\end{array}$ \\
\hline
\end{tabular}


sampai dengan 50 (lima puluh) hari kalender, sejak Masa Pelaksanaan berakhir.

45.4 Pemberian kesempatan kepada Penyedia untuk menyelesaikan pekerjaan dapat melampaui Tahun Anggaran.

Dari tabel 2 dapat dilihat perbedaaan, secara administrasi kapan addendum pemberian kesempatan dibuat seperti tabel 3 berikut:

Tabel 3.

Administrasi Addendum Pemberian Kesempatan Dibuat

\begin{tabular}{|c|c|c|}
\hline Ketentuan & $\begin{array}{l}\text { Administrasi Pembuatan } \\
\text { Addendum }\end{array}$ & Penjelasan \\
\hline Perpres No 16 Tahun 2018 & $\begin{array}{c}\text { Setelah pelaksanaan } \\
\text { kontrak berakhir }\end{array}$ & $\begin{array}{l}\text { Dalam hal Penyedia } \\
\text { menyelesaikan pekerjaan sampai } \\
\text { masa pelaksanaan Kontrak berakhir }\end{array}$ \\
\hline $\begin{array}{l}\text { SDP berdasar Keputusan Deputi Bidang } \\
\text { Pengembangan Strategi Dan Kebijakan LKPP }\end{array}$ & $\frac{\text { Setelah pelaksanaan }}{\text { kontrak berakhir }}$ & $\begin{array}{l}\text { Dalam hal Penyedia gagal } \\
\text { menyelesaikan pekerjaan sampai }\end{array}$ \\
\hline $\begin{array}{l}\text { Nomor } 3 \text { Tahun } 2018 \text { Tentang Standar } \\
\text { Dokumen Pemilihan Melalui Tender, } \\
\text { Seleksi, Dan Tender Cepat Untuk Pengadaan } \\
\text { Barang/Jasa Lainnya/Jasa Konsultansi }\end{array}$ & & masa pelaksanaan Kontrak berakhir \\
\hline $\begin{array}{l}\text { Standar Dokumen berdasar PerMenPUPR } \\
\text { Nomor 07/Prt/M/2019 Tentang Standar Dan } \\
\text { Pedoman Pengadaan Jasa Konstruksi Melalui } \\
\text { Penyedia }\end{array}$ & $\frac{\text { Sebelum pelaksanaan }}{\text { kontrak berakhir }}$ & $\begin{array}{l}\text { Dalam hal diperkirakan Penyedia } \\
\text { gagal menyelesaikan pekerjaan } \\
\text { sampai Masa Pelaksanaan berakhir }\end{array}$ \\
\hline
\end{tabular}

Dari tabel 3 sementara dapat disimpulkan addendum pemberian kesempatan untuk pengadaan "barang/jasa lainnya" dilakukan setelah pelaksanaan kontrak berakhir. Namun demikian, sebaiknya dalam klausul draft kontrak maupun kontrak dijelaskan kapan addendum pemberian kesempatan dibuat bilamana PPK memberikan kesempatan kepada penyedia untuk menyelesaikan pekerjaan. Dalam praktek perjanjian kredit, apabila nasabah mengalami masalah kredit macet, pada umumnya jika dilakukan rescheduling masih pada saat nasabah masih memiliki masa tanggungan hutang terhadap bank. Model rescheduling seperti ini bisa diterapkan kapan addendum pemberian kesempatan dibuat dalam pengadaan "barang/jasa lainnya".

Addendum pemberian kesempatan untuk pengadaan "jasa konstruksi" (pekerjaan konstruksi dan jasa konsultansi konstruksi) dilakukan sebelum pelaksanaan kontrak berakhir. Dari kesimpulan sementara seperti tabel 3 dapat dimungkinkan terjadi praktek administrasi pemberian kesempatan seperti tabel 4 berikut: 
Tabel 4.

Kemungkinan Terjadi Praktek Administrasi Pemberian Kesempatan

\begin{tabular}{lccc}
\hline \multicolumn{1}{c}{ Jenis Pengadaan } & \multicolumn{2}{c}{ Administrasi Pembuatan Addendum } \\
\hline "barang/jasa lainnya" & $\begin{array}{c}\text { Setelah pelaksanaan } \\
\text { kontrak berakhir } \\
\text { Sebelum pelaksanaan } \\
\text { kontrak berakhir }\end{array}$ & $\begin{array}{c}\text { Sebelum pelaksanaan } \\
\text { kontrak berakhir } \\
\text { Setelah pelaksanaan } \\
\text { kontrak berakhir } \\
\text { konstruksi dan jasa konsultansi } \\
\text { konstruksi) }\end{array}$ & $\begin{array}{c}\text { Tidak dilakukan } \\
\text { kontak dilakukan }\end{array}$ \\
\hline
\end{tabular}

Sepanjang tidak ada unsur kerugian negara dan tipikor, administrasi dalam pekerjaan pengadaan barang/jasa dapat

dilihat dalam tabel 5 sebagai berikut: (Sujoko 2019)

Tabel 5.

Praktik Administrasi dalam Pekerjaan Pengadaan Barang/Jasa

\begin{tabular}{|c|c|c|c|c|}
\hline $\begin{array}{l}\text { Pemenuhan } \\
\text { Administrasi }\end{array}$ & Dilakukan oleh & $\begin{array}{c}\text { Prosedur } \\
\text { administrasi }\end{array}$ & Administrasi & $\begin{array}{c}\text { Potensi masalah } \\
\text { administrasi }\end{array}$ \\
\hline Ada administrasi & $\begin{array}{c}\text { memiliki } \\
\text { kewenangan }\end{array}$ & $\begin{array}{c}\text { sesuai } \\
\text { salah prosedur }\end{array}$ & $\begin{array}{c}\text { benar } \\
\text { kesalahan } \\
\text { administrasi }\end{array}$ & $\begin{array}{c}\text { tidak ada } \\
\text { ada }\end{array}$ \\
\hline & $\begin{array}{l}\text { tidak memiliki } \\
\text { kewenangan }\end{array}$ & $\begin{array}{c}\text { sesuai } \\
\text { salah prosedur }\end{array}$ & $\begin{array}{l}\text { cacat wewenang } \\
\text { kesalahan } \\
\text { administrasi dan } \\
\text { cacat wewenang }\end{array}$ & $\begin{array}{l}\text { ada } \\
\text { ada }\end{array}$ \\
\hline $\begin{array}{c}\text { Tidak ada } \\
\text { administrasi }\end{array}$ & $\begin{array}{c}\text { memiliki } \\
\text { kewenangan }\end{array}$ & - & $\begin{array}{l}\text { kesalahan } \\
\text { administrasi }\end{array}$ & ada \\
\hline
\end{tabular}

\section{Kontrak dalam Pengadaan Barang/Jasa Pemerintah dan Persinggungan dalam Hukum Administrasi Negara}

Kebebasan berkontrak merupakan landasan bagi pemerintah dalam melakukan tindakan kontraktualisasi (Simamora 2009). Berdasar asas kebebasan berkontak ini, Pemerintah lazim membuat draft kontrak sebelum proses tender dilakukan. Posisi penyedia dihadapkan pada situasi take it or leave it (Simamora 2009). Manakala draft kontrak itu diterima dalam proses tender, maka syarat dan kondisi dalam kontrak akan berlaku dan mengikat pada saat draft kontrak ditandatangani.

Beberapa pandangan mengenai aspek hukum dalam kontrak pengadaan barang/jasa pemerintah. Yohanes Sogar
Simamora memberikan pendapat dalam kontrak PBJP: (Simamora 2009)

"Kontraktualisasi oleh pemerintah dilakukan dalam kapasitasnya sebagai subjek hukum privat (civil actor) dan dimungkinkan karena adanya prinsip kebebasan berkontrak. Sekalipun kontrak yang terbentuk tergolong sebagai kontrak privat dan bukan administrative contract, dalam kontrak komersial oleh pemerintah bekerja prinsip dan norma hukum publik, bersama-sama dengan prinsip dan norma hukum privat sebagai implikasi kedudukan pemerintah sebagai subjek hukum publik (public actor) yang tidak terlepaskan."

Kontrak administrasi (administrative contract) berlaku aturan khusus yakni Hukum Administrasi dan sebagai 
konsekuensinya kontrak jenis ini menjadi yurisdiksi peradilan administrasi (Simamora 2009). Jika dilihat dari praktik perkembangan penyelesaian permasalahan hukum terkait kontrak PBJP, maka kontrak PBJP masuk dalam kontrak privat, terlebih adanya penerapan teori melebur (opplosing theory).

Penulis berpendapat adanya aspek hukum administrasi negara dalam PBJP, termasuk dalam kontrak PBJP karena:

a. Pengadaan barang/jasa pemerintah menginduk pada peraturan yang sifatnya administrasi. Tindakan pemerintah yang menimbulkan akibat hukum dapat terdiri dari aspek hukum perdata (administrasi keperdataan) dan aspek hukum public (Sujoko 2019). Menurut Eman Suparman memiliki pandangan aspek hukum yang terkait kontrak PBJP sebagai berikut:

"sekalipun hubungan hukum yang terbentuk antara pemerintah dengan mitranya adalah hubungan kontraktual, tetapi di dalamnya terkandung tidak saja hukum privat, tetapi juga hukum publik. Apabila dalam kontrak komersil para pihak mempunyai kebebasan yang sangat luas dalam mengatur hubungan hukum atau mengatur kewajiban kontraktual mereka, maka dalam kontrak pengadaan oleh pemerintah, kebebasan itu tidak sepenuhnya berlaku sebab terhadap kontrak ini berlaku rezim hukum khusus."(Eman Suparman 2014)

b. Penyelesaian kontrak dalam PBJP tidak selalu diselesaikan menggunakan murni aspek keperdataan. Sebagai contoh adalah kasus penyelesaian pekerjaan yang sudah dilakukan oleh penyedia dan belum dibayar namun tidak ada kontraknya. Penyelesaian kasus semacam ini biasanya dilakukan proses audit, kemudian dibuat kontrak hutang untuk membayar pekerjaan. Proses penyelesaian semacam ini bukan mengikuti prinsip asas kebebasan berkontak, namun keleluasan adanya bentuk penyempurnaan administrasi dalam Undang-Undang Nomor 30 Tahun 2014 tentang Administrasi Pemerintahan. Terkait dengan sanksi akibat ketentuan dalam kontrak seperti sanksi daftar hitam. Dalam hal penyedia meminta pencabutan daftar hitam, maka pencabutannya ke PTUN (Mudjisantosa 2019).

c. Kontrak dalam PBJP tidak dipandang dari sebelum/pra kontrak, saat tanda tangan kontrak dan pelaksanaan/berakhirnya kontrak saja, namun dilihat dari sebelum kontrak, tanda tangan kontrak, pelaksanaan/berakhirnya kontrak serta setelah pelaksanaan kontrak secara utuh. Cara pandang ini akan berbeda dengan kontrak PBJP yang hanya dilihat sampai pelaksanaan kontrak. Dalam praktiknya setelah pelaksanaan kontrak, beberapa kasus kontrak PBJP ditemukan adanya kerugian Negara yang cara penyelesainnya tidak mengacu hukum perdata, namun dapat dilakukan dengan hukum administrasi. Pasca pelaksanaan kontrak perlu diakomodir dalam memandang kontrak PBJP. Dari beberapa praktek berkontrak dalam PBJP, ada beberapa klausul kontrak yang sifatnya melindungi secara sepihak di pihak pemerintah. Misalnya klausul apabila berdasar audit/bukti yang ditemukan ada kelebihan pembayaran, maka penyedia bersedia menyetor kelebihan pembayaran ke Kas Negara/Kas Daerah. Dalam pekerjaan konstruksi juga terdapat klausul yang sifatnya masih membebankan dan menjadi tanggung jawab penyedia, meskipun pelaksanaan kontrak sudah selesai. Klausul ini bisa didapat dalam 
tangung jawab penyedia secara kontraktual mengenai kegagalan bangunan.

d. Dalam kontrak komersial oleh pemerintah bekerja prinsip dan norma hukum publik sebagaimana pandangan Yohanes Sogar Simamora.

Menurut pendapat penulis dalam kontrak PBJP hubungan hukum dalam kontrak PBJP adalah adanya area persinggungan aspek hukum administrasi dengan hukum perdata. Dalam persinggungan ke dua aspek ini terjadi semacam tarik ulur berbagai teori dan penerapan asas pada masing-masing aspek. Sebelum diterapkan adanya teori melebur, permasalahan terkait pra kontrak dalam PBJP diajukan dalam yurisdiksi administrasi (Pengadilan Tata Usaha Negara). Dalam perkembangannya terkait permasalahan terkait dengan pra kontrak (proses pemilihan penyedia sampai dengan penunjukan penyedia) dalam PBJP masuk dalam hukum privat. Dapat dilihat dari cara penyelesaian permasalahan, persinggunan dari aspek hukum administrasi dengan hukum perdata dalam PBJP adalah bagaimana dan kemana penyelesian secara efektif harus dilakukan. Dari perkembangan tersebut, aspek hukum pasca pelaksanaan kontrak belum disinggung lebih lanjut seperti apa. Area persinggungan aspek hukum administrasi dengan hukum perdata sebagaimana dalam gambar 1 berikut:

\section{Gambar 1. Area Persinggungan Aspek Hukum Administrasi dengan Hukum Perdata dalam Kontrak PBJP}

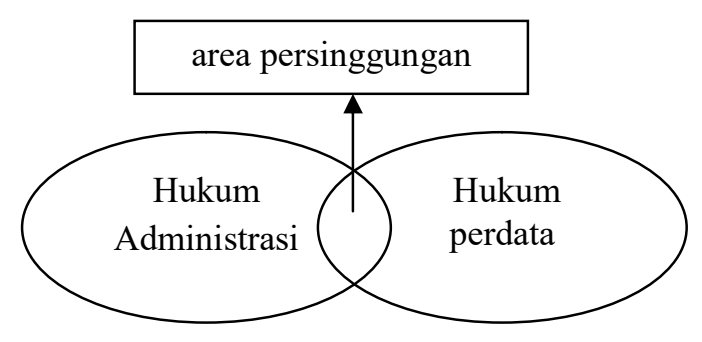

Dari area persinggungan aspek hukum administrasi dengan hukum perdata dalam kontrak PBJP, penulis menyebut dengan "kontrak administrasi keperdataan" (kontrak privat dalam lapangan hukum administrasi/privat-administrative contract). Hal ini berbeda dengan kontrak administrasi (administrative contract). Kontrak administrasi merupakan salah satu jenis kontrak yang dilakukan oleh Pemerintah Perancis, selain kontrak privat biasa, berlaku aturan khusus yakni Hukum Administrasi dan sebagai konsekuensinya kontrak jenis ini menjadi yurisdiksi peradilan administrasi (Simamora 2009). Kontrak privat biasa berlaku aturan hukum privat dan sebagai konsekuensinya menjadi yurisdiksi peradilan umum.

Kontrak lapangan hukum administrasi menurut penulis akan berbeda konsekuensinya dengan kontrak administrasi maupun kontrak privat. Penulis menawarkan konsep yurisdiksi peradilan khusus di bidang PBJP terkait penanganan permasalahan jika dilakukan secara litigasi. Alasan adanya peradilan khusus di bidang PBJP sangat relevan dewasa ini dan bisa mengakomodir kebutuhan penyelesaian permasalahan yang berkaitan dengan kontrak PBJP melalui jalur litigasi. Konsep peradilan khusus di bidang PBJP menurut penulis adalah menyelesaikan permasalahan administrasi, hukum dan teknis terkait permasalahan PBJP sejak pra kontrak, tanda tangan kontrak, pelaksanaan kontrak dan pasca pelaksanaan kontrak dengan biaya murah dan cepat.

Tabel 6 berikut menggambarkan perbedaan dan persamaan jenis kontrak dalam PBJP menurut kontrak administrasi, kontrak privat dan Privat-Administrative Contract: 
Tabel 6.

Perbedaan dan Persamaan Jenis Kontrak dalam PBJP

\begin{tabular}{|c|c|c|c|}
\hline \multicolumn{3}{|c|}{ Perbedaan Jenis Kontrak Dalam PBJP } & \multirow[t]{2}{*}{ Persamaan } \\
\hline Kontrak Administrasi & Kontrak Privat Biasa & $\begin{array}{c}\text { Privat-Administrative Contract } \\
\text { (konsep menurut penulis) }\end{array}$ & \\
\hline $\begin{array}{l}\text { Dipandang } \text { dari } \\
\text { sebelum/pra kontrak, saat } \\
\text { tanda tangan kontrak dan } \\
\text { pelaksanaan/berakhirnya } \\
\text { kontrak }\end{array}$ & $\begin{array}{l}\text { Dipandang dari sebelum/pra } \\
\text { kontrak, saat tanda tangan } \\
\text { kontrak } \\
\text { pelaksanaan/berakhirnya } \\
\text { kontrak }\end{array}$ & $\begin{array}{l}\text { Dipandang } \text { dari sebelum/pra } \\
\text { kontrak, saat tanda tangan } \\
\text { kontrak } \\
\text { pelaksanaan/berakhirnya } \\
\text { kontrak serta setelah } \\
\text { pelaksanaan/berakhirnya } \\
\text { kontrak secara utuh }\end{array}$ & \\
\hline $\begin{array}{l}\text { Berlaku } \\
\text { administrasi }\end{array}$ & Berlaku hukum privat & $\begin{array}{l}\text { Berlaku hukum administrasi } \\
\text { dan hukum privat }\end{array}$ & \\
\hline $\begin{array}{l}\text { Yurisdiksi } \\
\text { administrasi }\end{array}$ & Yurisdiksi peradilan umum & Yurisdiksi peradilan khusus & \\
\hline $\begin{array}{l}\text { Pembatasan asas kebebasan } \\
\text { berkontrak }\end{array}$ & $\begin{array}{l}\text { Asas kebebasan berkontrak } \\
\text { (menganut sistem terbuka), } \\
\text { meskipun dalam prakteknya } \\
\text { ada pembatasan }\end{array}$ & $\begin{array}{l}\text { Pembatasan kebebasan } \\
\text { berkontrak, sejalan dengan } \\
\text { cara pandang Pancasila, harus } \\
\text { dipahami sebagai kebebasan } \\
\text { yang terbatas }\end{array}$ & $\begin{array}{l}\text { antara } \\
\text { Pemerintah } \\
\text { dengan } \\
\text { Penyedia }\end{array}$ \\
\hline $\begin{array}{l}\text { Penyelesaian permasalahan } \\
\text { dengan hukum administrasi }\end{array}$ & $\begin{array}{l}\text { Penyelesaian permasalahan } \\
\text { dengan hukum privat }\end{array}$ & $\begin{array}{l}\text { Penyelesaian permasalahan } \\
\text { dengan hukum administrasi dan } \\
\text { hukum privat }\end{array}$ & \\
\hline $\begin{array}{l}\text { Penyelesaian melalui } \\
\text { peradilan administrasi }\end{array}$ & $\begin{array}{l}\text { Dapat dilakuan penyelesaian } \\
\text { sengekta non litigasi }\end{array}$ & $\begin{array}{l}\text { Dapat dilakuan penyelesaian } \\
\text { sengekta non litigasi }\end{array}$ & \\
\hline $\begin{array}{l}\text { Dikenal istilah } \\
\text { "kewenangan, hak dan } \\
\text { kewajiban" dalam kontrak }\end{array}$ & $\begin{array}{l}\text { Dikenal istilah "hak dan } \\
\text { kewajiban" dalam kontrak }\end{array}$ & $\begin{array}{l}\text { Dikenal istilah "kewenangan, } \\
\text { hak dan kewajiban" dalam } \\
\text { kontrak }\end{array}$ & \\
\hline
\end{tabular}

\section{Asas Kebebasan Berkontrak Dalam Pemberian Kesempatan Penyelesaian Pekerjaan Pengadaan Barang/Jasa Pemerintah}

Realita menunjukkan bahwa tidak setiap persoalan hukum dapat dipecahkan hanya dengan mengandalkan aturan hukum, ada persoalan hukum yang harus ditemukan jawabannya melalui prinsip hukum (Simamora 2009). Demikian juga dalam menemukan permasalahan yang ada seperti pemberian kesempatan penyelesaian pekerjaan PBJP. Pemberian kesempatan penyelesaian pekerjaan merupakan upaya agar pekerjaan yang diperjanjikan dalam kontrak dapat selesai.

Secara normatif, Pasal 56 Perpres 16 tahun 2018 dijelaskan seperti apa pemberian kesempatan. Beberapa surat perjanjian/kontrak PBJP yang sudah mengacu pada Standar Dokumen Pemilihan berdasar Keputusan Deputi Bidang Pengembangan Strategi Dan Kebijakan
LKPP Nomor 3 Tahun 2018 Tentang Standar Dokumen Pemilihan Melalui Tender, Seleksi, Dan Tender Cepat Untuk Pengadaan Barang/Jasa Lainnya/Jasa Konsultansi maupun berdasar PerMenPUPR Nomor 07/Prt/M/2019 Tentang Standar Dan Pedoman Pengadaan Jasa Konstruksi Melalui Penyedia terdapat klausul mengenai pemberian kesempatan penyelesaian pekerjaan. Pemberian kesempatan menyelesaikan kontrak berdasar Perpres 16 tahun 2018 adalah kewenangan PPK (Mudjisantosa 2018).

Adanya penerapan teori melebur (opplosing theory), dimana kontrak PBJP merupakan kontrak privat biasa, kontrak yang ditandatangani oleh kontraktan merupakan setingkat undang-undang Pasal 1338 ayat (1) KUHPerdata. Dalam pemberian kesempatan kepada penyedia merupakan hubungan yang sifatnya masih kontraktual. Dilihat kontrak PBJP merupakan kontrak privat, artinya hubungan 
kontraktual didasarkan pada antara "hak dan kewajiban" antara kontraktan sebagai upaya menyelesaikan pekerjaan, bukan sebagai kewenangan pemerintah sebagai kontraktan. Ketika pemberian kesempatan ini diberikan oleh pemerintah sebagai kontraktan kepada penyedia, maka didasarkan pada asas kebebasan berkontrak. Artinya pemerintah sebagai kontraktan bebas untuk menentukan upaya penyelesaian pekerjaan dengan penyedia walaupun masa pelaksanaan kontrak yang sudah diberikan sesuai perjanjian telah selesai. Ketika pemberian kesempatan ini diberikan dengan "dibuat administrasi" berupa addendum pemberian kesempatan, bukan berarti administrasi semacam ini mengikuti aspek hukum administrasi Negara, namun tetap mengikuti ketentuan-ketentuan dalam kontrak. Implikasinya, jika tidak terdapat "administrasi" pemberian kesempatan maka hal semacam ini bukan kesalahan administrasi, melainkan adanya pelanggaran ketentuan kontrak.

Lain halnya dengan cara pandang menurut penulis, berdasar konsep PrivatAdministrative Contract, maka pemerintah sebagai kontraktan memiliki kewenangan dalam menentukan apakah pemberian kesempatan dapat diberikan. Pemberian kesempatan bukan lagi dipandang pada "hak dan kewajiban" dalam berkontrak, namun wewenang pemerintah sebagai kontraktan dalam mengupayakan pekerjaan yang dilakukan oleh penyedia dapat selesai. Asas legalitas dalam bidang pemerintahan telah memberikan pemahaman bahwa segala tindak pemerintahan harus didasarkan pada wewenang yang bersumber pada peraturan perundang-undangan (Susanto 2019). Kontrak PBJP merupakan peraturan perundang-undangan yang setingkat undang-undang berdasar Pasal 1338 ayat (1) KUH Perdata. Ketika opsi pemberian kesempatan diberikan kepada penyedia, namun secara prosedural keliru, maka hal semacam ini masuk dalam kesalahan administrasi menurut hukum administrasi Negara.

\section{Simpulan}

Kontrak PBJP termasuk kontrak baku yang terdapat pembatasan asas kebebasan kontrak. Pemberian kesempatan penyelesaian pekerjaan dalam PBJP dilihat dari penerapan teori melebur (opplosing theory), merupakan kontrak privat. Hubungan antara kontraktan sebagai upaya menyelesaikan pekerjaan, bukan sebagai kewenangan pemerintah sebagai kontraktan, namun pada hubungan kontraktual didasarkan pada antara "hak dan kewajiban". Berdasar konsep PrivatAdministrative Contract, pemberian kesempatan bukan lagi dipandang pada "hak dan kewajiban" dalam berkontrak, namun wewenang pemerintah sebagai kontraktan dalam mengupayakan pekerjaan yang dilakukan oleh penyedia dapat selesai.

\section{DAFTAR PUSTAKA}

Budiono, Herlien. 2006. Asas Keseimbangan Bagi Hukum Perjanjian Indonesia, Hukum Perjanjian Berlandaskan Asas-Asas Wigati Indonesia. PT. Citra Aditya Bakti.

Budiwati, Septarina. n.d. "Asas Kebebasan Berkontrak Dalam Perspektif Pendekatan Filosofis.” Pp. 276-89 in.

Elis Herlina dan Sri Santi. 2016. "Model Perjanjian Baku Pada Kontrak Berlangganan Sambungan Telekomunikasi Telepon Selular Pasca Bayar." Jurnal Hukum IUS QUIA IUSTUM NO. 3 VOL.:415-38.

Eman Suparman. 2014. Aspek Hukum Pengadaan Barang/Jasa Pemerintah.

Hardjowahono, Bayu Seto. 2013. Naskah Akademik Rancangan Undang Undang Hukum Kontrak.

Hendrawati, Dewi. 2011. "Dalam Pembuatan Perjanjian Baku ( Studi Normati f Pada Perjanjian Pembiayaan Konsumen )." MMH 40 No. 4 O:41118. 
Hernako, Agus Yudha. 2010. Hukum Perjanjian Asas Proporsionalitas Dalam Kontrak Komersial. PT Kharisma Putra Utama.

Jamilah, Lina. 2012. "Dalam Perjanjian Standar Baku." Syiar Hukum, FH UNISBA XIII(8):227-43.

Mudjisantosa. 2018. Solusi Kontrak Pemerintah.

Mudjisantosa, Arthur Halik Razak. 2019. Solusi Kontrak (Membahas Kuiz 9-15). CV. Primaprint.

Santoso, Budi and Ratih Dheviana Puru H. T. 2012. "Dalam Perjanjian Kerja." Arena Hukum 6 Nomor 3,:201-9.

Simamora, Yohanes Sogar. 2009. Hukum Perjanjian Prinsip Hukum Kontrak Pengadaan Barang Dan Jasa Oleh Pemerintah. LaksBang PRESSindo.
Sujoko, Ajik. 2018. "Menggagas Sistem Pengupahan Dan Kesejahteraan Pekerja Outsourcing Di Pemerintah Dalam Pengadaan Publik." Adminitrative Law \& Governance Journal 1(November):436-46.

Sujoko, Ajik. 2019. Di Antara Perspektif Lain Tipikor Dalam Pengadaan Barang/Jasa Pemerintah. CV. Primaprint.

Susanto, Sri Nur Hari. 2019. "Karakter Yuridis Sanksi Hukum Administrasi: Suatu Pendekatan Komparasi." Adminitrative Law \& Governance Journal 2(1):126-42.

Thai, Khi V. 2001. "Public Procurement ReExamined." Journal of Public Procurement 1(1):9-50. 